\title{
Levroux, Montbaron
}

$\mathrm{n}^{\circ} 064477$

\section{Armelle Querrien}

\section{(2) OpenEdition}

\section{Journals}

Édition électronique

URL : http://journals.openedition.org/adlfi/14032

ISSN : 2114-0502

Éditeur

Ministère de la culture

\section{Référence électronique}

Armelle Querrien, «Levroux, Montbaron», ADLFI. Archéologie de la France - Informations [En ligne],

Centre, mis en ligne le 03 mars 2015, consulté le 03 mai 2019. URL : http://journals.openedition.org/ adlfi/14032

Ce document a été généré automatiquement le 3 mai 2019.

(C) Ministère de la Culture et de la Communication, CNRS 


\section{Levroux, Montbaron}

$n^{\circ} 064477$

\section{Armelle Querrien}

Lien Atlas (MCC) :

http://atlas.patrimoines.culture.fr/atlas/trunk/index.php?

ap_theme=DOM_2.01.02\&ap_bbox=1.578;46.930;1.696;47.019

1 Une première campagne de fouille s'est déroulée au mois d'août sur le site de Montbaron, repéré par avion et étudié par prospections électriques. Une partie du fossé de l'enclos pentagonal de $100 \mathrm{~m}$ par $100 \mathrm{~m}$ environ, qui entoure le site, a été fouillé. Il était en usage au XII $-\mathrm{XIII}^{\mathrm{e}} \mathrm{s}$. Il recoupe un petit fossé. Dans l'enclos, un silo a été mis au jour; d'après le rare mobilier trouvé dans le comblement il pourrait appartenir à la période gauloise, de même que le petit fossé et plusieurs fosses. Au nord de l'enclos se trouvent deux platesformes fossoyées. Un sondage dans le fossé des plates-formes montre que le comblement est riche en matériel du XIII ${ }^{\mathrm{e}} \mathrm{s}$.

2 Le site est très arasé et il n'y a que rarement des relations stratigraphiques entre les structures. La fouille doit continuer dans le secteur des plates-formes en 1999.

De nombreux prélèvements ont été effectués et une étude des pollens est déjà en cours. Des comparaisons avec le site de la motte de Moulins-sur-Céphons, occupé $\mathrm{du} \mathrm{XI}^{\mathrm{e}}$ au Xve $\mathrm{s}$. et situé à une dizaine de kilomètres à la limite du Boischaut et de la Champagne seront faites. 
INDEX

Index géographique : Centre, Indre (36), Levroux

Mots-clés : silo, fossé, plate-forme

operation Fouille programmée (FP)

Index chronologique : Moyen Âge 